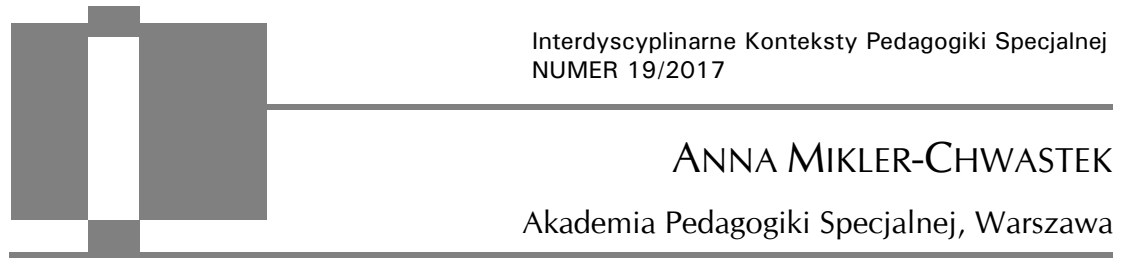

\title{
Inny we wczesnym systemie opieki i wychowania
}

\begin{abstract}
Anna Mikler-Chwastek, „Inny” we wczesnym systemie opieki i wychowania [The other in the early system of care and education]. Interdyscyplinarne Konteksty Pedagogiki Specjalnej, nr 19, Poznań 2017. Pp. 39-50. Adam Mickiewicz University Press. ISSN 2300-391X

In the Polish child care system for the disabled children do not lack any interesting solutions. However, the lack of coherence in the management of individual groups of small-child outreach facilities causes some solutions cannot be fully implemented. This problem concerns the system of nurseries and early support the development of children.
\end{abstract}

KEY WORDS: small child, supporting the development, nursery

\section{Małe dziecko niepełnosprawne}

W przypadku wykrycia u dziecka lub choćby podejrzenia niepełnosprawności czy innych deficytów, jak najszybciej warto podjąć wieloprofilowe działania mające na celu wspomaganie jego rozwoju. Wpłynie to nie tylko na poprawę aktualnego stanu, ale może przyczynić się do zmniejszenia lub wręcz zniwelowania problemów, które mogą pojawić się w przyszłości ${ }^{1}$. Wiele zaburzeń ma

${ }^{1}$ E. Reczek, Wczesna interwencja w Krakowie, „Światło i Cienie” 1997, nr 3. 
bowiem tendencje do pogłębiania się z wiekiem, zatem im szybciej dziecko zostanie poddane terapii, tym większe prawdopodobieństwo, że uniknie wielu trudności wtórnych.

Trzeba także pamiętać o specyfice rozwoju i dojrzewania układu nerwowego człowieka. Łatwiej kompensować pewne deficyty rozwojowe, gdy człowiek jest młodszy. Ma to ścisły związek z tzw. plastycznością mózgu, polegającą na zdolności neuronów do ulegania trwałym przekształceniom².

Pewne czynniki uszkadzające komórki OUN, takie jak: stres, niektóre z czynników środowiskowych, niedokrwienie, niedotlenienie, obrzęk mózgu, choroby neurodegeneracyjne pobudzają procesy naprawcze, prowadzące do tworzenia nowych neuronów. Neurogeneza w stanach patologicznych, poprzez naprawę samouszkodzeń danych obszarów, zapewnia zdolność do prawidłowego funkcjonowania mózgu. Największą zdolność do naprawy uszkodzeń ma rozwijający się układ nerwowy. Intensywność procesów naprawczych i zdolności kompensacyjne ulegają osłabieniu wraz z wiekiem³ ${ }^{3}$.

Z powyższego wynika, że małe dzieci szybciej czynią postępy rozwojowe, gdyż ich układ nerwowy jest podatniejszy na oddziaływania niż ma to miejsce w przypadku osób dorosłych ${ }^{4}$.

Skoro tak dużo wiadomo na temat wczesnej stymulacji, można zatem wnioskować, że zaniechanie terapii z powodu utrudnionego do niej dostępu może skutkować nieodwracalnymi zmianami w układzie nerwowym dziecka. Może także uniemożliwić dalsze postępy rozwojowe, na takim poziomie, który pozwoliłby np. na

2 M. Borkowska, Uwarunkowania rozwoju ruchowego i jego zaburzenia w mózgowym porażeniu dziecięcym, Warszawa 2001, s. 32.

${ }^{3}$ Cytat pochodzi z J. Dorszewska, Neurogeneza i plastyczność synaptyczna ośrodkowego układu nerwowego, [w:] Apoptoza w chorobach ośrodkowego układu nerwowego, red. W. Kozubski, J. Dorszewska. Czelej, Lublin 2008, s. 45-64; K. Wójcik, Neurobiologia rozwojowa i inwolucyjna plastyczności mózgu, [w:] Neurokognitywistyka w patologii $i$ zdrowiu, Pomorski Uniwersytet Medyczny, Szczecin 2009-2011, s. 165.

${ }^{4}$ R. Stefańska, Wczesna interwencja terapeutyczna - nadzieja i szansa na lepsze jutro dziecka, „Światło i Cienie” 1997, nr 3. 
wdrożenie dziecka w środowisko rówieśnicze ${ }^{5}$. Zatem aby skutecznie wspierać rozwój małego dziecka z niepełnosprawnością, potrzebna będzie organizacja całego systemu pomocowego dla niego $i$ jego rodziny.

\section{System wsparcia dla rodziców małych dzieci niepełnosprawnych}

W Polsce rodzic, którego dziecko zmaga się z trudnościami rozwojowymi, zgodnie z prawem może liczyć na różnego rodzaju wsparcie w postaci, np. zasiłków finansowych i ulg podatkowych. Są to m.in.:

- świadczenie pielęgnacyjne,

- zasiłek pielęgnacyjny,

- zasiłek rodzinny,

- dodatek do zasiłku rodzinnego z tytułu kształcenia i rehabilitacji dziecka niepełnosprawnego,

- dofinansowanie z PFRON do turnusów rehabilitacyjnych, sprzętu rehabilitacyjnego, przedmiotów ortopedycznych i środków pomocniczych,

- ulga rehabilitacyjna - rozliczając się z urzędem skarbowym, rodzic ma prawo odliczyć od swojego dochodu wydatki poczynione na rehabilitację,

- pomoc z NFZ (Fundusz Zdrowia może sfinansować częściowo zakup przedmiotów ortopedycznych i pomocniczych oraz długoterminową opiekę pielęgniarską).

Wymienione wyżej oferty dotyczą pomocy finansowej. Rodzice mogą także liczyć na wsparcie psychologiczne. Uczestniczą w działalności różnego typu grup wsparcia i grup samopomocowych, jednak powstają one jako oddolna inicjatywa. Fundacje i stowarzy-

5 Tekst opracowany na podstawie A. Mikler-Chwastek, Dotykowe poznawanie otoczenia. Diagnoza i wspomaganie rozwoju matych dzieci, Wydawnictwo APS, Warszawa 2011, s. 16-17. 
szenia, oferujące szeroko zakrojoną pomoc powstają często dzięki rodzicom dzieci niepełnosprawnych, jako reakcja na brak rozwiązań systemowych. Trzeba przy tym pamiętać o tym, że świadczenia i pomoc finansowa to tylko część całej gamy potrzeb. Równie istotne staje się zorganizowanie fachowej pomocy w postaci wieloprofilowego wspomagania rozwoju dziecka, u którego wykryto niepełnosprawność.

Wychodząc naprzeciw potrzebom dzieci i ich rodzin, w roku 2013 stworzono narzędzie umożliwiające świadczenie dodatkowego wsparcia w postaci Wczesnego wspomagania rozwoju (WWRD).

\section{Wczesne wspomaganie rozwoju dziecka niedostępne w żłobku}

Rozporządzenie MEN z dnia 11 października 2013 r. określa warunki organizowania wczesnego wspomagania rozwoju dzieci, mającego na celu pobudzanie psychoruchowego i społecznego rozwoju dziecka od chwili wykrycia niepełnosprawności do podjęcia nauki w szkole 6 . Zatem rozporządzeniu podlegają małe dzieci, u których wykryto i udokumentowano niepełnosprawność. Jednak tu pojawia się pewna trudność. Owo wczesne wspomaganie może być organizowane w przedszkolu i w szkole podstawowej, w tym w specjalnych, a także $\mathrm{w}$ innych formach wychowania przedszkolnego i ośrodkach ${ }^{7}$ oraz w publicznych i niepublicznych poradniach psychologiczno-pedagogicznych, w tym poradniach specjalistycznych, jeżeli te placówki mają możliwość realizacji wskazań zawartych w opinii o potrzebie wczesnego wspomagania rozwoju dziec-

\footnotetext{
${ }^{6}$ Warto rozróżnić wczesną interwencję terapeutyczną (oddziaływanie medyczne i rehabilitacyjne) od wczesnego wspomagania rozwoju (oddziaływanie psychologiczne i pedagogiczne). Wczesną interwencję realizuje system zdrowia (NFZ, poradnie rehabilitacyjne), natomiast wczesne wspomaganie rozwoju realizuje oświata. Por. http:/ / www.zespoldowna.info/roznica-wczesna-interwencja-a-wczesne-wspo maganie.html/ [dostęp: 23.05.2017].

7 Art. 2 pkt 5 ustawy z dnia 7 września 1991 r. o systemie oświaty.
} 
ka, dysponują środkami dydaktycznymi i sprzętem, niezbędnymi do prowadzenia wczesnego wspomagania. Jednak rozporządzenie to nie dotyczy żłobków i klubów dziecięcych, które nie podlegają Ministerstwu Edukacji Narodowej, tylko Ministerstwu Rodziny, Pracy i Polityki Społecznej. W związku z tym dzieci uczęszczające do żłobków nie mogą uczestniczyć w procedurze wczesnego wspomagania rozwoju na terenie placówki, w której przebywają kilka godzin dziennie. Czyli placówki otaczające fachową opieką najmłodszych nie mogą świadczyć usług w postaci WWRD, choć ich podopieczni spełniają po temu określone warunki (np. posiadają opinię o potrzebie wczesnego wspomagania rozwoju).

Rozporządzenie dopuszcza możliwość organizacji WWRD na terenie domu (,zajęcia w ramach wczesnego wspomagania, w szczególności z dziećmi, które nie ukończyły 3. roku życia, mogą być prowadzone także $\mathrm{w}$ domu rodzinnym" ${ }^{8}$ ). Jednak trzeba pamiętać o tym, że już sama możliwość przebywania dziecka w grupie rówieśniczej stanowi rodzaj wspomagania jego rozwoju i można go dodatkowo wzmocnić działaniami terapeutycznymi organizowanymi na terenie placówki.

Powstaje pytanie, gdzie można znaleźć pomoc dla dziecka, które nie uczęszcza jeszcze do przedszkola, a boryka się z zaburzeniami rozwojowymi? Rozwiązaniem wydają się być żłobki integracyjne, w których oprócz codziennych zajęć w postaci zabaw, zajęć muzycznych, czynności samoobsługowych dziecko może skorzystać ze specjalistycznej pomocy dopasowanej do indywidualnych potrzeb (np. zajęcia Integracji Sensorycznej, rehabilitacja metodą Bobath). Tego typu zajęcia są oferowane przez żłobki integracyjne.

\section{Żłobek - miejsce na skuteczną terapię małego dziecka}

Dla rodzica, a szczególnie dla rodzica dziecka niepełnosprawnego, przejście dziecka do żłobka jest momentem trudnym. Mamy

8 Rozporządzenie Ministra Edukacji Narodowej z dnia 11 października 2013 r. w sprawie organizowania wczesnego wspomagania rozwoju dzieci, § 5. 1 . 
bowiem do czynienia z bardzo małym dzieckiem (poniżej trzeciego roku życia), które nie zgromadziło jeszcze zbyt wielu doświadczeń, zwłaszcza w obszarze relacji rówieśniczych. Poza tym w tym okresie trudności komunikacyjne są naturalną konsekwencją procesu rozwojowego i zdecydowana większość dzieci się z nimi boryka, co powoduje, że dorosły niepokoi się o to, jak tak małe dziecko w obcym środowisku będzie zgłaszało swoje potrzeby i niepokoje.

Warto pamiętać, że $\mathrm{w}$ przypadku żłobków doszło w Polsce niedawno do znaczącej zmiany $w$ ich zarządzaniu i organizacji. W dniu 4 lutego 2011 r. uchwalona została ustawa o opiece nad dziećmi w wieku do lat trzeh. Dzięki temu aktowi prawnemu żłobki nie podlegają już Ministerstwu Zdrowia, ale przeszły pod zarząd Ministerstwa Rodziny, Pracy i Polityki Społecznej. Co za tym idzie, zmianie uległ cały system sprawowania opieki, wychowania i wspierania rozwoju tak małego dziecka.

Dzięki zaangażowaniu Fundacji Rozwoju Dzieci im. J.A. Komeńskiego opracowano zalecenia w postaci dokumentu: Standardy jakości opieki i wspierania rozwoju dzieci do lat 39, Od opiekuna obecnie pracującego w placówce wymaga się, by zadbał o bezpieczeństwo dzieci, otaczał je troskliwą opieką, ale także potrafił zorganizować cały system wsparcia rozwojowego. W praktyce placówka powinna zapewnić dzieciom komfort funkcjonowania na wszystkich płaszczyznach. Zalecenia dotyczą chociażby organizacji sal i najbliższego otoczenia:

- kąciki tematyczne wyposażone są $\mathrm{w}$ prawdziwe przedmioty, - dzieci mają dostęp do materiałów stymulujących zmysły,

- dzieci mają dostęp do materiałów umożliwiających manipulację,

- wszystkie materiały i zabawki powinny być bezpośrednio dostępne dla dzieci,

- urządzenia wykonane przede wszystkim z materiałów naturalnych,

${ }^{9}$ M. Rościszewska-Woźniak, Standardy jakości opieki $i$ wspierania rozwoju dzieci do lat 3, Fundacja Rozwoju Dzieci im. J.A. Komeńskiego, Warszawa 2012. 
- dostępne są naturalne materiały do zabaw manipulacyjnych i konstrukcyjnych,

- zachowane jest naturalne ukształtowanie terenu, aby dzieci mogły biegać, wspinać się, kopać, grabić liście, podlewać rośliny itp.

Opiekunowie powinni stwarzać optymalne warunki dla rozwoju dzieci, zatem muszą:

- znać stadia rozwoju małego dziecka we wszystkich sferach rozwoju,

- znać zasady dotyczące profilaktyki i ochrony zdrowia, zapobiegania wypadkom,

- znać zasady zdrowego żywienia,

- znać dynamikę procesu grupowego, rozwoju jednostki w grupie, zasad tworzenia się relacji społecznych $w$ grupach dziecięcych,

- wiedzieć, jakie warunki sprzyjają tworzeniu się więzi i pozytywnych relacji społecznych małych dzieci,

- wiedzieć, w jaki sposób powinna być zaaranżowana przestrzeń, która służy rozwojowi małego dziecka,

- posiadać wiedzę dotyczącą pedagogiki małego dziecka,

- wiedzieć, jakie warunki powinny spełniać zabawki dla małych dzieci,

- posiadać wiedzę dotyczącą rozwoju seksualnego dziecka,

- posiadać wiedzę dotyczącą prawnych aspektów opieki nad dziećmi oraz ochrony przed krzywdzeniem,

- posiadać wiedzę dotyczącą medycyny ratunkowej,

- potrafić obserwować i interpretować zachowania dziecka w kontekście jego potrzeb rozwojowych,

- potrafić rozpoznawać sygnały dzieci dotyczące np. potrzeb fizjologicznych, zmęczenia, itp.,

- potrafić komunikować się z dzieckiem, stawiać mu pytania, prowadzić rozmowę, stymulować rozwój językowy,

- potrafić współpracować z innymi dorosłymi, komunikować się, dzielić zadaniami,

- posiadać umiejętność pracy z grupą, 
- potrafić organizować zajęcia wzbudzające ciekawość dzieci (plastyczne, muzyczne, ruchowe, kulinarne, przyrodnicze), - posiadać umiejętność rozwiązywania problemów,

- być gotowi do przeprowadzania zabaw ruchowych z dziećmi (w przypadku opiekunów z niepełnosprawnościami narządu ruchu, osoba ta pracuje w asyście osoby pełnosprawnej),

- potrafić dostrzegać problemy, z którymi borykają się dzieci i ocenić, czy potrzebne jest $\mathrm{w}$ danej sytuacji wsparcie specjalisty,

- potrafić udzielić dziecku pierwszej pomocy,

- potrafić planować i dokumentować pracę z dziećmi.

Zwrócono przy tym uwagę na cechy osobowościowe opiekuna, który powinien:

- posiadać w sobie gotowość do zmian, być ciekawym świata,

- być cierpliwy i potrafić kontrolować swoje zachowania,

- być uważny na otoczenie i inne osoby,

- posiadać gotowość do refleksji i krytycznego namysłu,

- posiadać gotowość do uczenia się,

- być akceptujący, powstrzymywać się od osądzania, oceniania,

- mieć w sobie gotowość do zabawy,

- być elastyczny (potrafi dostosować swoje działania do zmieniających się dynamicznie sytuacji),

- szanować odrębność drugiej osoby ${ }^{10}$.

\section{Metody wspierania rozwoju małych dzieci proponowane przez żłobki}

Wychodząc naprzeciw oczekiwaniom rodziców dzieci niepełnosprawnych, dyrektorzy i pracownicy żłobków starają się organizować system wsparcia. Choć system wczesnego wspomagania rozwoju dziecka nie może zadziałać formalnie $w$ warunkach żłobkowych, to wykorzystanie na co dzień wartościowych form i metod wspomagania oraz zatrudnianie fachowej kadry na szczęście jest możliwe.

${ }^{10}$ Zalecenia opracowano na podstawie M. Rościszewska-Woźniak, op. cit. 
Dzieci z zaburzeniami w obszarze żucia i gryzienia oraz borykające się z opóźnieniami w zakresie rozwoju mowy mogą liczyć na wsparcie logopedów. Rodzice mogą nauczyć się prawidłowej stymulacji, by móc kontynuować pracę logopedy w domu. Dzięki tej współpracy postępy dziecka są szybciej zauważalne, a proces terapeutyczny może być kontynuowany bez względu na obecność dziecka w placówce (np. podczas choroby lub wakacji).

Wiele placówek decyduje się na zatrudnienie psychologa, którego zadaniem jest przeprowadzenie często pierwszej diagnozy dziecka. W przypadku niektórych dzieci zaburzenia rozwojowe ujawniają się pod koniec pierwszego roku życia lub w okresie poniemowlęceym. Zatem to właśnie w żłobku pewne deficyty są odkrywane. Doświadczony opiekun potrafi ocenić, który jego podopieczny wymaga dodatkowego wsparcia. Psycholog dziecięcy ma do dyspozycji narzędzia, które może wykorzystać już w przypadku bardzo małych dzieci. Przykładem są choćby Karty Oceny Rozwoju Psychoruchowego (KORP) ${ }^{11}$.

Zadaniem psychologa jest także otoczenie opieką rodziców, którzy muszą zmierzyć się z zaburzeniami rozwoju tak małego dziecka.

Ciekawą ofertą skierowaną do dzieci borykających się z zaburzeniami rozwoju $\mathrm{w}$ obszarze motorycznym są zajęcia $\mathrm{z}$ fizjoterapeutą, często terapeutą NDT - Bobath. Ta metoda została uznana przez środowisko medyczne za niezwykle skuteczną, bezpieczną i przydatną $w$ terapii najmłodszych dzieci. Zadaniem fizjoterapeuty jest odpowiednie wpływanie na napięcie mięśniowe (obniżanie napięcia wzmożonego i podwyższanie obniżonego), wygaszanie nieprawidłowych odruchów, wyzwalanie ruchów zbliżonych do prawidłowych, utrwalanie zdobytych umiejętności ruchowych w codziennych czynnościach.

Co ważne, efekty uzyskane przy pomocy metody Bobath mogą być wzmacniane na gruncie domowym przez samych rodziców,

${ }^{11}$ Jest to są narzędzie wystandaryzowane, przeznaczone do wstępnej oceny rozwoju dziecka. Pozwala na ustalenie, czy diagnozowane dziecko rozwija się harmonijnie oraz zgodnie $\mathrm{z}$ oczekiwaniami rozwojowymi określonymi $\mathrm{w}$ ramach każdego przedziału wiekowego. 
którzy co prawda sami nie są specjalistami, ale na co dzień dbają o odpowiednią pielęgnację dziecka, sposoby karmienia czy zaba$w^{12}$. Właściwie przygotowani przez terapeutę lepiej poradzą sobie $\mathrm{z}$ realizacją podstawowych zadań, ale także będą mogli kontynuować serię ćwiczeń $\mathrm{w}$ domu ${ }^{13}$.

Innym ważną metodą wspomagania rozwoju jest muzykoterapeuta. W żłobkach praktykuje się zajęcia rytmiczne i muzyczne, ale wiele placówek wprowadza także elementy terapii muzyką ${ }^{14}$. Warto zwrócić uwagę na Mobilną Rekreację Muzyczną, w której wykorzystuje się źródła dźwięku związane z ciałem (klaskanie, tupanie, gwizdanie itp.), a także wzmacnia działania muzyki o ćwiczenia rytmiczne, ruchowe, oddechowe, wyobrażeniowe, relaksacyjne, perkusyjne, formy plastyczne, literackie i teatralne. Autor tej metody, Maciej Kierył określił jej pięć podstawowych etapów, które daje się sprowadzić do pięciu słów kluczowych: odreagowanie, zrytmizowanie, uwrażliwienie, rekreacja, aktywizacja tworzący skrót OZURA:

Etap 1. - O, czyli odreagowanie (klaskanie, tupanie, podskoki, krzyk), wykonywanie kilku prostych, spontanicznych, dynamicznych ruchów.

Etap 2. - Z, zrytmizowanie, czyli wzmacnianie rytmu muzyki poprzez ruch czy grę na instrumentach.

${ }^{12} \mathrm{~W}$ metodzie Bobath, która często jest wykorzystywana w przypadku dzieci niepełnosprawnych ruchowo, np. borykających się z mózgowym porażeniem dziecięcym terapeuta uczy rodziców, jak we właściwy sposób opiekować się dzieckiem, jak je nosić, karmić, przewijać, po to, by wzmocnić efekty terapeutyczne. Taka organizacja terapii pozwala także na uniknięcie utrwalania nieprawidłowych wzorców.

${ }^{13}$ M. Matyja, M. Domagalska, Podstawy usprawniania neurorozwojowego wedtug Berty i Karla Bobathów, Wydawnictwo Śląskiej Akademii Medycznej, Katowice 1998; Z. Szwiling, P. Zawitkowski, Podstawy pielegnacji i opieki nad matym dzieckiem wo zasad NDT-Bobath, [w:] Warszawskie warsztaty neurologiczne. Materiaty wybrane 19961997, Poradnia Diagnostyki i Terapii Neurologicznej POLEK, Wydawnictwo Polskiego Stowarzyszenia Terapeutów NDT-SI, Warszawa 1998, http://www.ndt-bobath. pl/?page_id=65/ [dostęp: 29.05.2017].

${ }^{14}$ Por. M. Kieryl, Mobilna Rekreacja Muzyczna - MRM, http://www.zdrowamu zyka.pl/pdf/mrm.pdf/ [dostęp: 29.05.2017]. Por. http://www.zlobki.waw.pl/zlob ki.php/poradnik.php?z=23\&pid=14799 [dostęp: 29.05.2017]. 
Etap 3. - U, czyli uwrażliwienie poprzez integrację muzyki z plastyką, literaturą, może również polegać na samodzielnej grze na prostych instrumentach.

Etap 4. - R, rekreacja, polega na nauce różnych form odpoczyn$\mathrm{ku} \mathrm{z}$ wykorzystaniem muzyki, ćwiczenia oddechowe w pozycji leżącej lub siedzącej.

Etap 5. - A, czyli aktywizacja poprzez ćwiczenia rytmiczne, taniec, śpiew. Aktywizacja łagodna (spokojne ćwiczenia w pozycji leżącej, przechodzenie do pozycji stojącej przez siad); aktywizacja dynamiczna (ćwiczenia w tempie).

Terapia Integracji Sensorycznej (SI) to kolejny ciekawy sposób na uzupełnienie trapi dzieci z zaburzeniami rozwojowymi. Wiele placówek inwestuje $\mathrm{w}$ specjalistyczne wyposażenie sal ${ }^{15}$ i szkolenie terapeutów, gdyż metoda SI może być wykorzystana już w przypadku bardzo małych dzieci.

Już najmłodsze dzieci mające trudności w obszarze SI zmagają się z: nadmierną wrażliwością na bodźce sensoryczne, zbyt małą lub zbyt dużą wrażliwością na stymulację sensoryczną, mają za wysoki lub za niski poziom aktywności ruchowej, borykają się $\mathrm{z}$ trudnościami z koncentracją uwagi, mają niższe umiejętności ruchowe, problemy z koordynacją, wykazują opóźnienie rozwoju w obszarze mowy. Tego typu zachowania są widoczne już u dzieci $\mathrm{w}$ okresie poniemowlęcym, zatem zasadne wydaje się wykorzystanie metody SI na terenie żłobka.

\section{Podsumowanie}

Choć program Wczesnego Wspomagania Rozwoju Dziecka nie znajduje zastosowania w przypadku żłobków (nie są one zarządzane przez MEN, a zatem nie podlegają jego prawodawstwu), mimo

15 Sala do terapii SI jest odpowiednio wyposażona, chodzi m.in. o huśtawki, wałki, materace, trampoliny. Por. http://poradnia-ada.pl/sala-integracji-sensorycz nej-si/ [dostęp: 29.05.2017]. 
to dyrektorzy i opiekunowie starają się tak zorganizować wsparcie, by wyjść naprzeciw potrzebom dzieci i ich rodziców. Wiele placówek zarówno publicznych, jak i niepublicznych zatrudnia fachowy personel, inwestuje potrzebne w wyposażenie. Zatem rodzice moga wykorzystać program Wczesnego Wspomagania Rozwoju Dziecka na terenie domu (jest taka możliwość prawna) i skorzystać z wartościowej oferty żłobków, co z pewnością wpłynie korzystnie na przebieg rozwoju dziecka.

\section{Bibliografia}

Borkowska M., Uwarunkowania rozwoju ruchowego i jego zaburzenia w mózgowym porażeniu dziecięcym, Warszawa 2001.

Dorszewska J., Neurogeneza i plastyczność synaptyczna ośrodkowego układu nerwowego, w: Apoptoza w chorobach ośrodkowego układu nerwowego, red. W. Kozubski, J. Dorszewska, Czelej, Lublin 2008.

http://www.ndt-bobath.pl/?page_id=65/ [dostęp: 29.05.2017].

http:/ / www.zespoldowna.info/roznica-wczesna-interwencja-a-wczesne-wspomaga nie.html/ [dostęp 23.05.2017].

http:/ / www.zlobek.duna.pl/ [dostęp: 23.05.2017].

Matyja M., Domagalska M., Podstawy usprawniania neurorozwojowego wedtug Berty i Karla Bobathów, Wydawnictwo Śląskiej Akademii Medycznej, Katowice 1998.

Mikler-Chwastek A., Dotykowe poznawanie otoczenia. Diagnoza i wspomaganie rozwoju małych dzieci, Wydawnictwo APS, Warszawa 2011.

Reczek E., Wczesna interwencja w Krakowie, „Światło i Cienie” 1997, nr 3.

Rościszewska-Woźniak M., Standardy jakości opieki i wspierania rozwoju dzieci do lat 3, Fundacja Rozwoju Dzieci im. J.A. Komeńskiego, Warszawa 2012.

Rozporządzenie Ministra Edukacji Narodowej z dnia 11 października 2013 r. w sprawie organizowania wczesnego wspomagania rozwoju dzieci.

Stefańska R., Wczesna interwencja terapeutyczna - nadzieja i szansa na lepsze jutro dziecka, „Światło i Cienie” 1997, nr 3.

Szwiling Z., Zawitkowski P., Podstawy pielegnacji i opieki nad matym dzieckiem wg zasad NDT-Bobath, [w:] Warszawskie warsztaty neurologiczne. Materiaty wybrane 19961997, Poradnia Diagnostyki i Terapii Neurologicznej POLEK, Wydawnictwo Polskiego Stowarzyszenia Terapeutów NDT-SI, Warszawa 1998.

Ustawa z dnia 7 września 1991 r. o systemie oświaty.

Wójcik K., Neurobiologia rozwojowa i inwolucyjna plastyczności mózgu, [w:] Neurokognitywistyka w patologii i zdrowiu, Pomorski Uniwersytet Medyczny, Szczecin 2009-2011. 